\title{
MAGT1 Gene
}

National Cancer Institute

\section{Source}

National Cancer Institute. MAGT1 Gene. NCI Thesaurus. Code C157561.

This gene is involved in protein glycosylation and magnesium ion transport. 